Winna Tedjasukmono, Eko Harry Susanto: Fenomenologi Pengguna Vape pada Perempuan di Komunitas@Dragoncloudz.id

\title{
Fenomenologi Pengguna Vape pada Perempuan di Komunitas @Dragoncloudz.id
}

\author{
Winna Tedjasukmono, Eko Harry Susanto \\ winnapinkts@gmail.com,ekoharry@yahoo.com \\ Fakultas Ilmu Komunikasi Universitas Tarumanagara
}

\begin{abstract}
The phenomenon of the use of vape is one of the things widely discussed by the public. This research wants to see a vape user community consisting of women who are members of the Instagram group @ dragoncloudz.id because the community is one of the communities that shows Vape Trick to its members. The purpose of this study was to determine the meaning of vape on female vape users on Instagram social media. This type of research is descriptive qualitative. Research data were collected using observations, interviews, literature studies, and documentation. The data collected was then tested for its validity using triangulation of data sources by Vaper Influencer sources and Vaper women. The results showed that the meaning of vaping activities for women vape users was as an art, hobby and could be used as a profession.
\end{abstract}

Keywords: art, instagram, interaction, phenomenon, vape, women.

\begin{abstract}
Abstrak
Saat ini muncul suatu tren di kalangan para perokok yaitu rokok elektrik atau vape. Penggunaan vape merupakan salah satu hal yang banyak diperbincangkan oleh masyarakat. Penelitian ini melihat satu komunitas pengguna vape yang terdiri dari perempuan. Dalam media sosial Instagram @dragoncloudz.id komunitas tersebut merupakan salah satu komunitas yang memperlihatkan vape trick kepada para anggotanya. Tujuan penelitian ini adalah untuk mengetahui makna vape pada perempuan pengguna vape di media sosial Instagram. Jenis penelitian ini adalah deskriptif kualitatif. Data penelitian dikumpulkan menggunakan observasi, wawancara, studi kepustakaan, dan dokumentasi. Data yang berhasil dikumpulkan selanjutnya diuji keabsahannya menggunakan triangulasi sumber data dengan narasumber influencer vape dan para perempuan pengguna vape. Hasil penelitian menunjukkan bahwa makna dari kegiatan vaping bagi perempuan pengguna vape tersebut adalah sebagai seni, hobi dan dapat dijadikan sebagai profesi.
\end{abstract}

Kata Kunci: fenomena, instagram, interaksi, perempuan, seni, vape.

\section{Pendahuluan}

Saat ini muncul rokok elektrik yang terbuat dari Gawai dan Likuid. Rokok elektrik digunakan sebagai pengganti rokok yang terbuat dari tembakau dan mengandung nikotin. Berbagai sumber dari mengenai sejarah vaporizer mengapresiasi seorang ahli farmasi China bernama Hon Lik sebagai pencipta gawai ini yang mematenkannya untuk pertama kali pada 2003. Walaupun sebuah artikel daring lain menunjukkan bahwa keberadaan paten pertama untuk gawai yang sangat mirip dengan vaporizer sekarang dapat dilacak hingga tahun 1927 (Wake and Vape 2015) Vaporizer baru benar-benar menjadi populer dan di konsumsi oleh sangat banyak penduduk dunia setelah Hon Lik mulai memproduksi dan memasarkan produknya. Alasan utama 
Hon Lik menciptakan gawai ini adalah agar dapat berhenti merokok setelah ayahnya meninggal dunia akibat kanker paru-paru (CASAA, 2012).

Terlepas dari berbagai wacana yang melatari fenomena ini, dinamika sosial dalam komunitas para pengguna vaporizer ini sendiri menjadi hal yang menarik terutama jika dikaitkan dengan berbagai praktik konsumsi yang terlibat di dalamnya. Berkembangnya zaman vape kini tidak lagi hanya digunakan oleh pria. Saat ini vape juga menjadi suatu ketertarikan bagi perempuan. Ketertarikan penulis untuk melakukan penelitian berawal saat melihat perempuan yang menggunakan vape di media sosial instagram. Penulis pun tertarik dengan salah satu akun instagram @ dragoncloudz.id yang berisi tentang video para perempuan pengguna vape yang melakukan trick dalam menghisap vape.

Pengguna rokok elektrik khususnya perempuan menganggap bahwa rokok elektrik lebih sehat dari rokok yang mengandung nikotin. Oleh karena itu peneliti tertarik untuk mengetahui lebih dalam bagaimana fenomenologi di benak perempuan pengguna vape khususnya didalam komunitas @dragoncloudz.id.

Rumusan masalah dalam penelitian ini adalah Bagaimana Fenomena pengguna vape pada komunitas vape dalam komunitas @ dragoncloudz.id?

Tujuan dari penelitian ini adalah untuk mengetahui fenomena penggunaan vape di benak para perempuan dalam komunitas @dragncloudz.id.

Penelitian ini dilakukan berdasarkan analisis teori komunikasi dan konsep mengenai fenomena. Komunikasi adalah sebuah proses pertukaran pesan antara dua pihak atau lebih yang bertujuan untuk menyampaikan pesan dalam satu kesepahaman (Cangara, 2014; Liliweri, 2011: West dan Turner, 2008).

Penulis melakukan analisis dengan media sosial khususnya Instagram, yang dijadikan wadah oleh para perempuan pengguna vape dalam berinteraksi. Perempuan pengguna vape tersebut memiliki satu komunitas di Instagram yaitu @ dragoncloudz.id.

Perkembangan teknologi komunikasi yang mendukung penyebaran pesan dengan cepat melalui televisi, surat kabar, telepon seluler, internet dan perangkat elektronik lainnya, semakin memudahkan komunikasi manusia (Dr. Eko Harry Susanto; Teori Komunikasi Manusia)

\section{Metode Penelitian}

Studi literatur yang dilakukan oleh penulis yaitu melakukan pencarian terhadap buku, arsip, artikel, dan jurnal yang merupakan rujukan untuk memperkuat penelitian ini. Subjek dalam penelitian ini adalah bagaimana benak perempuan pengguna vape yang tergabung dalam komunitas Instagram @dragoncloudz.id. Sementara objek dalam penelitian ini adalah fenomena dan makna kepada perempuan pengguna vape. Data penelitian yang teliti kumpulkan menggunakan empat metode, yaitu observasi, wawancara, studi kepustakaan, dan dokumentasi. Data yang berhasil dikumpulkan selanjutnya diuji keabsahannya menggunakan triangulasi sumber data dan dianalisis menggunakan analisis kualitatif sesuai tahapan analisis yang dikemukakan oleh Bungin (2012), yaitu Pengumpulan Data, Reduksi Data, Penyajian Data, dan Penarikan Kesimpulan. 
Winna Tedjasukmono, Eko Harry Susanto: Fenomenologi Pengguna Vape pada Perempuan di Komunitas@Dragoncloudz.id

\section{Hasil Temuan dan Diskusi}

Menurut Audrey vape merupakan suatu hal yang menyenangkan dan bukan hal yang menakutkan.

Berikut kutipan wawancara dengan Audrey : "Aku gabung sama mereka sebenernya jadi salah satu influencer-nya. Nah aku enjoy ngejalanin kegiatan aku ini. Sering sih denger : kan lu cewe. Kok mau sih ngevape segala macem? Bahaya buat kesehatan kan? Tapi banyak juga kok berita yang mengatakan bahwa vape itu aman dan lebih menyehatkab dibandingkan rokok. Dari pengalaman yang aku dapet juga bener kok. Rata-rata temen-temen aku yang ngevape lebih fresh dari pada geng yang merokok. Jelas beda banget sih (Audrey, Influencer Vape, 16 November 2019)."

Audrey tergabung dalam komunitas vape karena tertarik ketika melihat temannya menggunakan vape

"Aku gabung sama mereka sebenernya jadi salah satu influencernya. Nah aku enjoy ngejalanin kegiatan aku ini. Sering sih denger : kan lu cewe. Kok mau sih ngevape segala macem? Bahaya buat kesehatan kan? Tapi banyak juga kok berita yang mengatakan bahwa vape itu aman dan lebih menyehatkan dibandingkan rokok. Dari pengalaman yang aku dapet juga bener kok. Ratarata temen-temen aku yang ngevape lebih fresh dari pada geng yang merokok. Jelas beda banget sih"

\section{Media Sosial}

Menurut Audrey makna kegiatan vaping adalah sebuah kegiatan yang dapat menambah pengetahuan serta dapat memperluas pergaulannya.

"Aku ngevape bukan karena ikut-ikutan terus udahan gitu ya, kalo sekarang kan aku udah jadiin vape sebagai hobby dan pekerjaan. Aku bisa menghasilkan uang dengan hobby aku. Jadi walaupun diluar orang-orang bilang ngevape itu ga bagus dan lain-lain aku ga peduli sih. Karena aku tumbuh di lingkungan yang mengerti dan paham betul tentang vape ini”"

Sama seperti Audrey, menurut Meli kegiatan vaping merupakan suatu kegiatan yang dapat dilakukan bersama teman-teman.

"Aku penasaran, lalu ada akun instagramnamanya@dragoncloudz.id. Nah dia selain jual liquid juda ada komunitasnya. Jadi aku langsung Join. Sejak ikut komunitas ini ketemu temen-temen yang daerahnya deket rumah, kita jadi suka saling ngajarin gimana sih cara untuk buat trick kaya gitu. Akhirnya dari sana baru deh pemikiranku berubah tentang Vape. Awalnya kan coba-coba. Lalu aku sempet bosen. Sekarang ini jadi hobby aku”"

Sedangkan menurut Elli vaping merupakan sebuah kegiatan yang dilakukannya untuk mengganti kegiatan merokoknya menjadi hal yang lebih positif.

"Jadi bagi gua vape itu kaya penyelamat sih, bisa ngilangin kecanduan gw sama rokok dan bikin badan gw juga berasa lebih sehat. Soalnya walaupun vape asepnya banyak itu sebenernya bukan asep tapi UAP"

Berdasarkan hasil penelitian, penulis menyimpulkan bahwa para perempuan pengguna vape di @dragoncloudz.id saling berbagi pengalaman dan informasi 
mengenai vaping sehingga mereka dapat mengembangkan sebuah komunitas yang di dalamnya terdapat banyak anggota yang makin bertambah dan saling bertukar pengalaman serta informasi mengenai vape.

\section{Hubungan Interaksi dan Pengguna Vape}

Berdasarkan hasil penelitian penulis, media sosial merupakan suatu wadah untuk para perempuan anggota @dragoncloudz.id untuk saling berinteraksi, berbagi informasi serta berkomunikasi sehingga terbentuk ikatan sosial yang membuat mereka saling berkumpul dan membentuk suatu komunitas. Analisa penulis dalam penelitian ini adalah para anggota @dragoncloudz.id melakukan aktivitas yaitu berkomunikasi dengan orang lain sehingga dapat membangun makna vape sebagai suatu hal yang berbeda. Hal ini dikarenakan komunikasi yang dibangun antara para anggota vaping tersebut membangun sebuah makna subjektif terhadap vaping itu sendiri. Melalui komunikasi di social media tersebut para anggota juga melakukan pertukaran ide, berbagi informasi serta pengetahuan yang dapat membuat mereka merasa nyaman berada di dalam komunitas tersebut.

\section{Fenomena Vape pada Pengguna Perempuan}

Penulis merangkum bahwa manusia mengambil tindakan dan bersikap dalam kehidupan sehari hari berdasarkan dari pengalaman. Individu bersikap spontan dan langsung dari apa yang di alami dan berdasarkan objek yang dilihat. Berdasarkan hasil penelitian yang penulis lakukan bahwa para informan melakukan kegiatan vaping berdasarkan apa yang sudah mereka alami dan rasakan pada saat melakukan kegiatan tersebut.

\section{Makna Vaping pada Anggota Perempuan @dragoncloudz.id}

Makna dari objek yang terdapat di dunia nyata dihasilkan melalui pengalaman individu dengan objek tersebut. Aliran konstruktivis mememahami bahwa konsep dari makna yang dihasilkan oleh individu dikonstruksikan berdasarkan kumpulan pengetahuan (stock of knowledge) individu yang dipengaruhi oleh pengalamanpengalamannya. Realitas dari sebuah objek nyata merupakan keterkaitan individu terhadap objek tersebut (Bungin, 2009)

Berdasarkan hasil penelitian penulis serta wawancara dengan salah satu Informan penulis yaitu Audrey yang merupakan seorang influencer vaper. Berdasarkan pengalaman yang didapatnya bahwa vaping menjadi sebuah seni dan dijadikan sebagai profesi. Berdasarkan pengalaman yang dia dapatkan dari temanteman vaper lainnya Audrey juga mengatakan bahwa vaping sebenarnya merupakan sebuah alat untuk mengalihkan perokok untuk beralih ke vape yang jauh lebih sehat dibandingkan dengan rokok yang merekap hisap setiap harinya. Pernyataan Audrey diperkuat dengan artikel yang dibaca tentang dua rumah sakit di inggris yang mengatakan bahwa vape lebih sehat dibandingkan rokok.

\section{Kesimpulan}

1. Komunikasi antara perempuan anggota vaping di @ dragoncloudz.id membuat para anggota saling bertukar informasi dan pengetahuan tentang trick-trick dalam menggunakan vaping 
Winna Tedjasukmono, Eko Harry Susanto: Fenomenologi Pengguna Vape pada Perempuan di Komunitas@Dragoncloudz.id

2. Komunitas@dragoncloudz.id menggunakan media social Instagram untuk saling berkomunikasi, berbagi informasi serta mengirimkan video untuk para anggotanya saling belajar mengenai trick menggunakan vaping

3. Interaksi antar perempuan anggota @dragoncloudz.id membangun pemikiran subjektif tentang vape yaitu vape dianggap sebagai seni, hobby dan hal yang menyenangkan dan tidak berbahaya bagi kesehatan

4. Pengalaman para perempuan anggota @dragoncloudz.id membangun sebuah pemikiran bahwa fenomena vape adalah sebagai dari kesenangan dan sebuah wadah untuk mendapatkan penghasilan

5. Para perempuan pengguna vape memandang vape sebagai makna konotatif yaitu bukan makna yang berdasarkan dari hal-hal objektif. Sehingga dapat disimpulkan makna vape bagi para perempuan pengguna vape di komunitas @ dragoncloudz.id adalah sebagai suatu seni, hobby, pengganti rokok yang lebih sehat serta sebuah kegiatan yang dapat menghasilkan uang.

\section{Ucapan Terima Kasih}

Terimakasih kepada narasumber penelitian : Audrey Andrea, Meli Pradetha, dan Elli June.

\section{Daftar Pustaka}

Alex, Sobur (2009). Analisis Teks Media, Bandung.

Bogdan dan Taylor. (1975). Dalam Moleong (2002) Metodologi Kualitatif.

Eko Harry Susanto. (2018). Teori Komunikasi Manusia.

George Hebert Mead (1934) Mind, Self, and Society. Edited by Arthur. E. Murphy. Schutz, Alfred (1962) What Is Phenomenology? Chicago: Quadrangle Books Wilson, TD. 